\title{
CORRECTION
}

\section{Correction to: Osteitis fibrosa cystica von Recklinghausen}

\author{
Mehdi Maanaoui $^{1,2} \cdot$ Aghiles Hamroun $^{1,3} \cdot$ Céline Lebas $^{1} \cdot$ Rémi Lenain $^{1} \cdot$ Arnaud Lionet $^{1}$
}

Published online: 27 March 2021

(c) Italian Society of Nephrology 2021

\section{Correction to: Journal of Nephrology}

https://doi.org/10.1007/s40620-020-00961-4

While typesetting the article, the article type was published incorrectly as "Letter" instead of "ContinuingEducation".

Publisher's Note Springer Nature remains neutral with regard to jurisdictional claims in published maps and institutional affiliations.

The original article can be found online at https://doi.org/10.1007/ s40620-020-00961-4.

Mehdi Maanaoui

mehdi.maanaoui@gmail.com

1 Department of Nephrology, CHU Lille, 59000 Lille, France

2 INSERM, U1190, 59000 Lille, France

3 Center for Research in Epidemiology and Population Health (CESP), Clinical Epidemiology Team, National Institute of Health and Medical Research (INSERM), Villejuif, France 